\title{
A PRÁTICA PEDAGÓGICA HISTÓRICO-CRÍTICA E O ENSINO DE EDUCAÇÃO FÍSICA NA EDUCAÇÃO INFANTIL
}

\author{
Leonardo Docena Pina ${ }^{1}$
}

\begin{abstract}
RESUMO
O texto discute a prática pedagógica histórico-crítica na educação infantil, mais especificamente, no que se refere ao ensino de educação física. Além de defender o ato de ensinar como eixo nuclear do trabalho pedagógico na educação infantil, o texto apresenta uma experiência pedagógica que abordou a dimensão histórica que reveste o correr, saltar, lançar e arremessar. As reflexões apresentadas contribuem para reafirmar a viabilidade da pedagogia histórico-crítica para o ensino de educação física na educação infantil.

Palavras-chave: Pedagogia histórico-crítica. Educação infantil. Educação física. Prática pedagógica.
\end{abstract}

\section{HISTORICAL CRITICAL PEDAGOGIC PRACTICE AND TEACH OF PHYSICAL EDUCATION IN EARLY CHILDHOOD EDUCATION}

\begin{abstract}
This paper discusses the historical-critical pedagogical practice in early childhood education, specifically in physical education. Besides defending the act of teaching as nuclear axis of pedagogical work in early childhood education, the text presents an educational experience about the historical dimension that covers the running, jumping and throwing. The reflections presented contribute to reaffirm the viability of the historicalcritical pedagogy for teaching physical education in early childhood education.

Keywords: Historical critical pedagogy. Early childhood education. Physical education. Pedagogical practice.
\end{abstract}

\section{A pedagogia histórico-crítica e o ensino na educação infantil}

Na perspectiva da pedagogia histórico-crítica, a função da escola é socializar o conhecimento científico, filosófico e artístico produzido pela humanidade através dos tempos, em suas formas mais elevadas, razão pela qual se defende que a atividade de ensino escolar deve, portanto, visar uma ampliação dos horizontes culturais dos alunos, mediante a apropriação dos conhecimentos, produzindo novas necessidades e tendo como meta o desenvolvimento da sua personalidade como um todo (DUARTE e EIDT, 2007).

Essa definição sobre o papel da escola sustenta-se na perspectiva marxista de formação humana, na qual trabalho e educação são concebidos como atividades exclusivamente humanas (SAVIANI, 2007).

Por trabalho, entende-se a atividade teleológica de transformação da natureza para a produção de meios voltados à satisfação das necessidades humanas (MARX, 2004).

O ser humano, para produzir sua própria existência, necessitou transformar a natureza para satisfazer suas necessidades e, assim, com o trabalho, produziu uma realidade nova, sociocultural. Contudo, o próprio surgimento da vida em sociedade se deve à hominização dos antepassados animais, processo que, por sua vez, também resulta do 
trabalho, cujo surgimento e desenvolvimento modificaram a aparência física do homem, bem como a sua organização anatômica e fisiológica.

Conforme explica Leontiev (1978), as condições necessárias à execução das operações complexas do trabalho foram criadas, primeiro, pela passagem progressiva à posição vertical e, depois, pela formação correlativa de extremidades móveis livres da função de marcha e aptas para apanhar objetos. Podendo fabricar seus próprios instrumentos e utilizando-os nas mais diversas operações, os homens aperfeiçoaram seu principal órgão de trabalho, as mãos, como, também, seu psiquismo. $\mathrm{O}$ autor explica que, no início do desenvolvimento da sociedade, surgiu uma partilha entre os diversos participantes do processo de produção da existência, o que acarretou uma modificação profunda e radical da própria estrutura da atividade dos indivíduos que dela participavam. Numa relação dialética, a atividade que originou o desenvolvimento do cérebro e dos órgãos dos sentidos foi sendo, cada vez mais, impulsionada - pelo desenvolvimento do próprio psiquismo - a se aperfeiçoar, por meio de um processo no qual a estrutura da atividade e a estrutura da consciência determinaram-se dialeticamente. Em síntese, pode-se dizer que a uma determinada estrutura objetiva da atividade do ser social corresponde uma dada estrutura subjetiva. Em outras palavras,

a uma determinada realidade social, tanto material quanto simbólica, corresponde uma dada forma de consciência e personalidade (...). $\mathrm{Na}$ medida em que se desenvolvem qualitativamente as atividades humanas, aprimoram-se os produtos materiais e simbólicos dessas atividades. Esses produtos, por sua vez, irão determinar um grau superior de desenvolvimento humano tanto material quanto psíquico, ou seja, tanto no que se refere aos aspectos objetivos da existência social humana quanto no que diz respeito às aptidões e funções psíquicas dos indivíduos (ROSSLER, 2006, p. 102-103).

Por meio da atividade social, os seres humanos se relacionam com a realidade objetiva para assegurar sua existência e, justamente para melhor captar e compreender a realidade, processos mentais cada vez mais elaborados são requeridos e desenvolvidos. Dessa complexificação dos processos psíquicos se originam as "funções psicológicas superiores" (VYGOTSKI, 1995). Exclusivamente humanas, essas funções psíquicas resultam de processos eminentemente culturais e dependem de processos educativos para se desenvolverem, ou seja, não são garantidas pelo aparato biológico da espécie.

Assim como as funções psíquicas superiores, outros resultados do desenvolvimento histórico da humanidade não se reproduzem, nos seres humanos, pela hereditariedade. Para produzir sua própria existência, cada indivíduo singular, ao nascer, precisa formar-se enquanto ser humano, uma vez que "o homem não nasce homem. Ele forma-se homem. Ele não nasce sabendo produzir-se como homem. Ele necessita aprender a ser homem" (SAVIANI, 2007, p. 154). Para tanto, torna-se necessário desenvolver um processo que transmita, de geração em geração e a cada indivíduo singular, as faculdades e propriedades humanas historicamente produzidas. Assim explica Leontiev (1978, p.166):

O mundo real, imediato, do homem, que mais do que tudo determina a sua vida, é um mundo transformado e criado pela actividade humana. Todavia, ele não é dado imediatamente ao indivíduo, enquanto mundo de objectos sociais, de objectos encarnando aptidões humanas formadas no decurso do desenvolvimento da prática socio-histórica; enquanto tal, apresenta-se a cada indivíduo como um problema a resolver. 
A resolução desse problema a que se refere o autor reside na especificidade de um processo exclusivamente humano, qual seja, a apropriação da experiência acumulada pela humanidade ao longo da história social, cujo resultado é "a reprodução, pelo indivíduo, das aptidões e funções humanas, historicamente formadas" (LEONTIEV, 1978, p. 169). Pode-se dizer que a apropriação é "o processo pelo qual o homem atinge no seu desenvolvimento ontogênico o que é atingido, no animal, pela hereditariedade, isto é, a encarnação nas propriedades do indivíduo das aquisições do desenvolvimento da espécie" (LEONTIEV, 1978, p. 169). Portanto, trata-se de um processo graças ao qual se produz na criança o que, no animal, ocorre devido à hereditariedade: "a transmissão ao indivíduo das aquisições do desenvolvimento da espécie” (LEONTIEV, 1978, p. 320).

Ao analisar as características centrais desse processo, Duarte $(1999 ; 2003)$ aponta, dentre outros, o fato de que a apropriação se constitui sempre como um processo educativo. $\mathrm{O}$ autor explica que o indivíduo se forma apropriando-se dos resultados da história social e objetivando-se no interior dessa história. Dito de outra forma, a formação do indivíduo enquanto ser humano ocorre sempre no interior de relações concretas com outras pessoas, que atuam como mediadoras entre ele e o mundo da cultura, caracterizando um processo educativo, mesmo quando essa educação se realiza de forma espontânea, isto é, quando não há relação consciente com o processo educativo que está se efetivando no interior de uma prática social.

A essa concepção de formação humana, corresponde, segundo Duarte (2003), o conceito de trabalho educativo no qual se fundamenta a pedagogia histórico-crítica. Saviani (2005, p.13) define esse conceito como

o ato de produzir, direta e intencionalmente, em cada indivíduo singular, a humanidade que é produzida histórica e coletivamente pelo conjunto dos homens. Assim, o objeto da educação diz respeito, de um lado, à identificação dos elementos culturais que precisam ser assimilados pelos indivíduos da espécie humana para que eles se tornem humanos e, de outro lado e concomitantemente, à descoberta das formas mais adequadas para atingir esse objetivo.

Nessa linha, a tarefa a que se propõe a pedagogia histórico-crítica, em relação à educação escolar, implica: a) identificar as formas mais desenvolvidas em que se expressa o saber objetivo produzido historicamente, reconhecendo as condições de sua produção e compreendendo as suas principais manifestações bem como as tendências atuais de transformação; b) converter o saber objetivo em saber escolar, de modo que se torne assimilável pelos alunos no espaço e tempo escolares; c) prover os meios necessários para que os alunos não apenas assimilem o saber objetivo enquanto resultado, mas apreendam o processo de sua produção, bem como as tendências de sua transformação (SAVIANI, 2005).

Além de considerar que o saber é objetivo, porque reflete a realidade objetivamente existente, a pedagogia histórico-crítica entende que existem formas mais desenvolvidas de saber, uma vez que essa concepção pedagógica pauta-se no método dialético de Marx,

em cujo âmbito não há margem nem para o evolucionismo ingênuo (seja no plano da história da organização social humana, seja no plano da história do conhecimento), nem para o relativismo que nega a existência de formas mais desenvolvidas de vida social e de conhecimento, nem, finalmente, para o subjetivismo que nega o conhecimento como 
apropriação da realidade objetiva pelo pensamento (DUARTE, 2003, p.77).

Ao ressaltar esses fundamentos, torna-se evidente que tal perspectiva se contrapõe aos ideários contemporâneos dominantes, que frequentemente concebem o trabalho educativo como um processo de interação entre significados subjetivos e individuais em oposição à transmissão de um saber objetivo socialmente construído (DUARTE, 2003). Conforme já afirmamos, Saviani (2005) entende que a escola é uma instituição cujo papel consiste na socialização do saber sistematizado. Não se trata, portanto, de qualquer tipo saber: "a escola diz respeito ao conhecimento elaborado e não ao conhecimento espontâneo; ao saber sistematizado e não ao saber fragmentado; à cultura erudita e não à cultura popular" (SAVIANI, 2005, p.14). Longe de se constituir como uma desvalorização da cultura popular, esse posicionamento nos remete ao alerta de que o domínio da cultura erudita é importante para a participação política, tal como explica Saviani (2006, p.55):

Se os membros das camadas populares não dominam os conteúdos culturais, eles não podem fazer valer seus interesses, porque ficam desarmados contra os dominadores, que se servem exatamente desses conteúdos culturais para legitimar e consolidar sua dominação. (...) o dominado não se liberta se ele não vier a dominar aquilo que os dominantes dominam. Então, dominar o que os dominantes dominam é a condição de libertação.

No caso específico da Educação Infantil, foco do presente texto, a ausência de uma adequada compreensão sobre a importância do conhecimento científico transmitido pelo professor na formação do psiquismo da criança tende a contribuir para generalizar a ideia de que a Educação Infantil deve seguir os princípios de uma "pedagogia antiescolar". A utilização desse termo, conforme explica Arce (2004, p. 161-162), se deve ao fato de que tal perspectiva entende que "a escolarização, o ensino e a transmissão de conhecimentos são prejudiciais ao desenvolvimento da criança".

Segundo Arce (2004), o que mais tem atraído educadores para essa proposta denominada por seus defensores de "Pedagogia da Infância" - é exatamente o fato de ela reunir várias ideias contrárias ao caráter escolar da educação de crianças menores de seis anos, tais como: 1) o foco do trabalho educativo na aprendizagem provinda das construções individuais; 2) a inversão da ideia de que o adulto humaniza a criança, portanto, a infância passa a ser a portadora de todas as virtudes e de todas as forças que humanizariam os adultos; 3) o princípio de que o lúdico, isto é, o prazeroso, deve ser o eixo central da prática educativa; 4) a ausência de planejamento, a criança dita o ritmo do trabalho e o professor apenas a segue; 5) a crença de que trazer a comunidade e a cultura local para dentro da escola tornará a criança um cidadão melhor no futuro; 6) a crença de que conhecimento provindo da prática e retirado do cotidiano das crianças e professores vale mais do que qualquer livro; 7) a defesa do lema "aprender a aprender", ou seja, o professor não ensina, apenas acompanha, orienta, estimula, partilha; 8) a inexistência de um conhecimento universal, sendo este substituído por múltiplos significados, frutos de múltiplas leituras do cotidiano que devem ser negociados entre professores e alunos; 9) a negação da repetição como recurso pedagógico; 10) a ênfase nas múltiplas formas de comunicação que se diferenciem da "tradicional" transmissão verbal do conhecimento. Ao analisar essa perspectiva, a autora conclui que o que parece ser uma valorização real da criança e da infância "constitui-se em recurso ideológico de desvalorização da educação escolar e de alienação dos indivíduos desde a mais tenra idade" (ARCE, 2004, p. 164). 
Em oposição à pedagogia da infância, a pedagogia histórico-crítica compreende que a educação infantil integra a educação escolar e, portanto, deve reafirmar a formação humana tendo em vista as máximas possibilidades de desenvolvimento da criança. Por isso defende $o$ ato de ensinar nessa fase educativa a fim de promover uma primeira etapa do processo de superação das relações naturais e imediatas do sujeito com o mundo rumo a processos superiores, adquiridos mediante a apropriação de instrumentos culturais capazes de formar distintas capacidades na criança (PASQUALINI, 2010). Para tanto, o trabalho educativo deve ser organizado e dirigido pelo professor, de modo a transmitir aos alunos os resultados do desenvolvimento histórico da humanidade, dentre os quais se encontra o próprio desenvolvimento psíquico:

O desenvolvimento psíquico do indivíduo ocorre apenas no processo de apropriação dos conhecimentos e procedimentos elaborados histórica e socialmente. Por conseguinte, para que haja desenvolvimento é imprescindível que haja aprendizagem (...). Portanto, se o desenvolvimento do homem demanda aprendizagem, esta, por sua vez, requer o ensino. É pelo trabalho educativo que os adultos assumem um papel decisivo e organizativo junto ao desenvolvimento infantil, e da qualidade dessa interferência dependerá a qualidade do desenvolvimento (ARCE e MARTINS, 2010, p.54-55).

As capacidades humanas historicamente acumuladas só se formam nas crianças mediante a apropriação da experiência social, por meio de um processo organizado e dirigido pelo adulto, razão pela qual a pedagogia histórico-crítica - e também a psicologia histórico-cultural $^{2}$ - não pensam o papel do professor de educação infantil como alguém que apenas estimula e acompanha a criança em seu desenvolvimento. $\mathrm{O}$ educador deve ser compreendido "como alguém que transmite à criança os resultados do desenvolvimento histórico, medeia o processo de apropriação dos objetos culturais e organiza a atividade da criança” (PASQUALINI, 2011, p. 76).

Considera-se que apenas o ensino sistematicamente orientado à transmissão de conhecimentos científicos, tal como proposto pela pedagogia histórico-crítica, alia-se à formação das funções psíquicas superiores, na medida em que coloca a aprendizagem a serviço do desenvolvimento, tal como preconizado pela psicologia histórico-cultural (MARTINS, 2011).

Vale ressaltar que transmitir conhecimentos sistematizados na educação infantil não significa desconsiderar as especificidades dessa fase da educação escolar, a exemplo da importância do jogo de papeis como "atividade principal"3 no processo de desenvolvimento da criança em idade pré-escolar. Ao defender a centralidade da transmissão do conhecimento científico, consideramos - conforme Arce, Silva e Varotto (2011) - que a atividade a ser realizada na educação infantil é escolar. Porém, é importante lembrar que embora o professor vá trabalhar com Ciências, Matemática, História, Geografia, Língua Portuguesa, Artes, Música, Educação Física, o movimento na educação infantil é feito por ele de forma diferente da que usa no ensino fundamental, além do que,

a rotina de uma sala de educação infantil envolve, além do ensino, o cuidado com o corpo da criança, que possui necessidades peculiares por sua fase de desenvolvimento. Ademais, essas atividades de ensino são acessórias no processo de desenvolvimento da criança neste momento, não deixando de ser fundamentais para que as atividades principais se desenvolvam em sua plenitude (ARCE, SILVA e VAROTTO, 2011, p.38-39). 
Portanto, ao defender que o saber erudito seja transmitido às crianças da pré-escola, não desconsideramos a necessidade de adequar o conteúdo à faixa etária com a qual se trabalha. Por outro lado, situar o ensino como eixo articulador do trabalho pedagógico na educação de crianças menores de seis anos significa afirmar que a instituição de educação infantil é uma escola, e isso não é perverso, uma vez que as crianças são alunos e o trabalho pedagógico tem como pilar a transmissão de conhecimentos para revolucionar o desenvolvimento infantil sem perder de vista suas peculiaridades (ARCE, 2010).

\section{Educação Física na educação infantil: a prática pedagógica histórico-crítica}

O movimento pedagógico que deu origem à pedagogia histórico-crítica surge no final da década de 1970 como resposta à necessidade de encontrar alternativa à pedagogia dominante. Saviani (2005) explica que, naquele contexto, imperava a necessidade, especialmente no caso brasileiro, de criticar a pedagogia oficial para evidenciar seu caráter reprodutor. Contudo, além das críticas ao estabelecido, era necessário, segundo o autor, formular uma proposta pedagógica atenta aos determinantes sociais da educação, que permitisse articular o trabalho pedagógico com as relações sociais, levando em conta a ação recíproca em que a educação, embora determinada em suas relações com a sociedade, reage ativamente sobre o elemento determinante (SAVIANI, 2005). Assim, como desdobramento desse processo, emerge uma perspectiva articulada aos interesses da classe trabalhadora.

Nesse contexto, os questionamentos que ganharam força na década de 1980 sobre o vínculo da educação escolar com a reprodução do modo capitalista de produção da existência humana também colocaram em crise as referências que direcionavam a Educação Física por mais de um século. A inflexão na área, configurada como uma crise de legitimidade do "paradigma da aptidão física" 4 , abriu um período de buscas para se construir a autonomia pedagógica da área frente a um quadro histórico de vínculo ao projeto dominante. Um importante marco nesse processo foi a publicação, na década de 1990, do livro Metodologia do Ensino de Educação Física (COLETIVO DE AUTORES, 1992). Essa obra apresenta o paradigma da reflexão crítica sobre a cultura corporal - uma tendência que, pautada na pedagogia histórico-crítica, visa a formação do indivíduo enquanto sujeito histórico, crítico e consciente da realidade social em que vive.

Para formar esse tipo de sujeito, o paradigma da reflexão crítica sobre a cultura corporal defende a tematização dos conteúdos de forma crítico-superadora. A tematização proposta abrange a compreensão das relações de interdependência que os diferentes conteúdos da Educação Física têm com os grandes problemas sócio-políticos atuais, como "ecologia, papéis sexuais, saúde pública, relações de trabalho, preconceitos sociais, raciais, da deficiência, da velhice, distribuição do solo urbano, distribuição de renda, dívida externa e outros" (COLETIVO DE AUTORES, 1992, p. 62-63). Assim, busca-se desenvolver uma reflexão pedagógica sobre as formas de representação do mundo exteriorizadas pela expressão corporal que o ser humano tem produzido no decorrer da história, dentre as quais pode-se destacar: jogos, danças, lutas, exercícios ginásticos, esporte, malabarismos, contorcionismos, mímica e outros que integram uma área de conhecimento denominada de "cultura corporal".

Diferente das perspectivas centradas no desenvolvimento da aptidão física, o paradigma da reflexão crítica sobre a cultura corporal assume a escola como instituição responsável pela transmissão do conhecimento sistematizado, cuja apropriação pelos alunos é considerada fundamental para que compreendam a realidade. Nessa linha, cabe à 
Educação Física socializar o conhecimento historicamente acumulado sobre a cultura corporal.

No que pese todo avanço produzido por essa perspectiva, ainda é comum nos depararmos com questionamentos sobre sua viabilidade para o ensino de Educação Física, além do que há dúvidas sobre como "aplicar" seus fundamentos na prática pedagógica, motivos que nos levaram à produção deste texto.

A fim de oferecer elementos que nos ajudem a pensar como desenvolver o trabalho educativo na educação infantil com base nessa perspectiva, optou-se por elaborar e desenvolver um plano de trabalho com turmas do primeiro período da educação infantil ao primeiro ano do ensino fundamental de uma escola pública de Juiz de Fora. A escolha do conteúdo ocorreu mediante a necessidade de privilegiar a transmissão do conhecimento historicamente acumulado que reveste a dimensão histórica do correr, do saltar, do lançar e do arremessar, com o intuito de superar a "naturalização do histórico", processo que, comumente, reveste a compreensão desses movimentos corporais.

Para tanto, partimos de Engels (2004), que destaca a centralidade do trabalho no processo de produção e reprodução da cultura, evidenciando como a produção de meios, para satisfazer necessidades, foi, gradativamente, desenvolvendo a realidade sociocultural ${ }^{5}$. A abordagem de Engels (2004) nos permite compreender como se desenvolveram a postura bípede e as atividades dela decorrentes, dentre as quais se destacam as relacionadas aos movimentos corporais que, hoje, se apresentam com nova configuração no atletismo. Assim, buscamos reafirmar o entendimento de que

o homem não nasceu pulando, saltando, balançando, jogando etc. Todas essas atividades corporais foram construídas em determinadas épocas históricas, como respostas a determinados estímulos, desafios ou necessidades humanas (COLETIVO DE AUTORES, 1992, p.39).

Embora nos ajude a entender o desenvolvimento de diferentes atividades corporais - como, por exemplo, as que estão presentes atualmente no esporte, na luta, na dança e na ginástica - a noção de historicidade que reveste esses conteúdos tende a não ser apropriada pelos seres humanos em sua vida cotidiana. Trata-se de um conhecimento elaborado que necessita ser socializado por ampliar as capacidades de compreensão e explicação da realidade. Diante disso, questiono: como transmitir, aos alunos, a noção de historicidade da cultura corporal através do ensino do atletismo, com base nos fundamentos da pedagogia histórico-crítica? Será possível trabalhar esse tema/conteúdo com alunos da Educação Infantil? Para responder essas questões, faz-se necessário discutir a experiência pedagógica desenvolvida, que seguiu os cinco momentos metodológicos da pedagogia histórico-crítica: identificação da prática social, problematização, instrumentalização, catarse e prática social final $^{6}$.

\section{Identificação da prática social}

Segundo Saviani (2006), o ponto de partida do método dialético de transmissão do conhecimento escolar é a prática social. Trata-se de uma fase na qual possibilitamos um primeiro contato com o tema a ser estudado, de modo a mobilizar os alunos para o processo pedagógico (GASPARIN, 2005). Gasparin (2005) explica que a identificação da prática social pode ser dividida em anúncio e vivência cotidiana dos conteúdos. No anúncio dos conteúdos, aponta-se o que será estudado e quais os objetivos a serem alcançados. Na vivência cotidiana dos conteúdos, identifica-se o que os alunos já sabem e o que eles gostariam de saber mais sobre o assunto em questão. 
Assim, nesta fase, informamos aos alunos que estudaríamos o atletismo, dando ênfase às formas originais dos movimentos conhecidos como corrida, saltos, arremessos e lançamentos para que pudéssemos identificar sua importância para a manutenção da vida humana na Pré-história. Conforme consta no Quadro 1 - Unidades didáticas e seus objetivos, o trabalho pedagógico envolveu principalmente: a identificação das principais características da Pré-história; a reflexão sobre as formas originais e atuais dos saltos, corridas, lançamento e arremessos; a vivência dos movimentos, além da identificação das diferentes modalidades do atletismo.

\begin{tabular}{|ll|}
\hline \multicolumn{1}{|c|}{$\begin{array}{l}\text { UNIDADES } \\
\text { DIDÁTICAS }\end{array}$} & \multicolumn{1}{c|}{ OBJETIVOS GERAIS } \\
\hline & $\begin{array}{l}\text { - Refletir sobre as condições de vida na Pré-história, a fim de } \\
\text { relacionar a garantia da própria sobrevivência naquele contexto com a }\end{array}$ \\
$\begin{array}{l}\text { 1- Os movimentos } \\
\text { básicos do ser humano na } \\
\text { Pré-história }\end{array}$ & $\begin{array}{l}\text { necessidade de correr, saltar, lançar e arremessar; } \\
\text { - Identificar a corrida, o salto, o lançamento e o arremesso como } \\
\text { construções culturais que buscaram responder aos desafios impostos } \\
\text { pela natureza, de modo a compreender as formas originais de tais } \\
\text { movimentos corporais; } \\
\text { - Vivenciar brincadeiras que encenem os desafios impostos ao homem } \\
\text { pela natureza na Pré-história. }\end{array}$ \\
\hline $\begin{array}{l}\text { Os movimentos } \\
\text { 2- } \\
\text { básicos do ser humano } \\
\text { nas modalidades } \\
\text { atletismo }\end{array}$ & $\begin{array}{l}\text { - Identificar diferentes provas de atletismo que envolvem o saltar, o } \\
\text { - Compreender a corrida com obstáculo, a corrida sem obstáculo, o } \\
\text { salto em altura e o salto em distância do atletismo como expressões } \\
\text { contemporâneas dos movimentos básicos do homem; } \\
\text { - Experimentar, de forma não competitiva, diferentes modos de correr, } \\
\text { saltar, lançar e arremessar; }\end{array}$ \\
\hline
\end{tabular}

Quadro 1 - Unidades didáticas e seus objetivos Fonte: elaboração própria do autor

Na vivência cotidiana dos conteúdos, que também integra a identificação da prática social, buscou-se conhecer o que os alunos sabiam sobre o tema. Nesse momento, discutimos as seguintes questões gerais: vocês conhecem o atletismo? Alguém já viu uma prova de atletismo na televisão ou teve a oportunidade de praticar isso alguma vez? Quais são as provas que compõem o atletismo? Vocês sabem o que é a Pré-história? Quem vivia naquela época? O homem, antigamente, na Pré-história, praticava as modalidades que vemos hoje na televisão? Será que ele saltava, corria e lançava com o mesmo objetivo de hoje?

Juntamente com as questões, procuramos mostrar algumas imagens dos hominídeos da Pré-história, além de vídeos da contemporaneidade sobre o atletismo. Neste último caso, mostramos uma montagem com saltos (em altura e em distância), as corridas (com e sem obstáculo), o arremesso de peso e o lançamento de dardo, questionando se, antigamente, esses movimentos corporais eram utilizados com outras finalidades, não competitivas. Foi possível compreender que os alunos não dominavam um conhecimento elaborado que os permitissem responder as questões com propriedade, embora alguns 
tenham reconhecido o "homem das cavernas" e, ainda, manifestaram ter assistido algumas provas de atletismo pela televisão.

\section{Problematização}

O segundo passo do método dialético de transmissão do conhecimento é a problematização, fase na qual busca-se "detectar que questões precisam ser resolvidas no âmbito da prática social e, em conseqüência, que conhecimento é necessário dominar" (SAVIANI, 2006, p. 71). Conforme ressalta Gasparin (2005), a problematização é o momento no qual devemos selecionar e discutir os problemas que têm origem na prática social, mas, que, ao mesmo tempo, se ligam ao conteúdo a ser trabalhado: trata-se de uma seleção e discussão de grandes questões sociais, porém, inseridas e especificadas no conteúdo da unidade que está sendo estudada. Uma das tarefas a serem realizadas na problematização refere-se à seleção das dimensões do conteúdo a serem trabalhadas. Para tanto, pode-se partir do conteúdo a ser trabalhado, de modo a elaborar questões desafiadoras que expressem dimensões específicas referentes à natureza do conteúdo, como, por exemplo, as dimensões científico-conceituais, sociais, econômicas, culturais, históricas, filosóficas, morais, éticas, estéticas, legais e doutrinárias (GASPARIN, 2005).

Neste momento, formulamos algumas questões para trabalhar o conteúdo e tema selecionados.

\begin{tabular}{|c|c|}
\hline DIMENSÕES & QUESTÕES PROBLEMATIZADORAS \\
\hline Conceitual & $\begin{array}{l}\text { O que é a Pré-história? Quem vivia lá nessa época? Na Pré-história existia } \\
\text { atletismo? Salto em altura e salto em distância são a mesma coisa? }\end{array}$ \\
\hline Histórica & $\begin{array}{l}\text { Como e quando o ser humano adquiriu a postura bípede? Por que correr, } \\
\text { saltar e lançar eram tão importantes para a vida humana antigamente? }\end{array}$ \\
\hline Cultural & $\begin{array}{l}\text { Quais brincadeiras vivenciadas atualmente envolvem a corrida, os saltos, os } \\
\text { lançamentos ou os arremessos? }\end{array}$ \\
\hline Técnica & $\begin{array}{c}\text { Como os hominídeos produziam instrumentos para caçar? Como e para que } \\
\text { eles utilizavam fogo? Quais as diferentes formas de salto podemos utilizar } \\
\text { para ultrapassar um obstáculo? A corrida é importante para saltarmos ou } \\
\text { lançarmos mais longe? }\end{array}$ \\
\hline Moral & $\begin{array}{c}\text { Por que não precisamos estabelecer um ganhador para saltarmos, } \\
\text { lançarmos, corrermos e arremessarmos? }\end{array}$ \\
\hline
\end{tabular}

Quadro 2 - As dimensões do conteúdo a serem problematizadas

Fonte: elaboração própria do autor

\section{Instrumentalização}

A instrumentalização é o caminho através do qual o conteúdo sistematizado é posto à disposição dos alunos para que o assimilem, o recriem e, ao incorporá-lo, transformemno em instrumento cultural para transformação da realidade (GASPARIN, 2005). É nesse momento do método dialético de transmissão do conhecimento que os alunos vão se apropriar das ferramentas culturais necessárias à luta social que travam diariamente para se libertar das condições de opressão em que vivem; ou seja, trata-se da fase na qual ocorre a 
apropriação dos instrumentos teóricos e práticos necessários ao equacionamento das questões detectadas na prática social (SAVIANI, 2006).

No caso da experiência desenvolvida com o ensino do atletismo na educação infantil, a transmissão do conhecimento foi realizada principalmente a partir das seguintes atividades: exposição do professor sobre o conteúdo; visualização de vídeos e imagens que abordam o atletismo ou a vida humana na Pré-história; produção de desenhos; vivência de brincadeiras voltadas à encenação dos desafios impostos ao homem pela natureza na Préhistória; vivência de atividades não competitivas que se aproximam das modalidades de atletismo conhecidas como corrida com/sem obstáculo, salto em altura, salto em distância, arremesso de peso e lançamento de dardo.

\begin{tabular}{|c|c|c|c|}
\hline $\begin{array}{l}\text { Unidade } \\
\text { didática I }\end{array}$ & Objetivos & Procedimentos & Recursos \\
\hline $\begin{array}{c}\text { Os } \\
\text { movimentos } \\
\text { básicos do } \\
\text { ser humano } \\
\text { na Pré- } \\
\text { história }\end{array}$ & $\begin{array}{l}\text { - Refletir sobre as condições } \\
\text { de vida na Pré-história, a } \\
\text { fim de relacionar a garantia } \\
\text { da própria sobrevivência } \\
\text { naquele contexto com a } \\
\text { necessidade de correr, } \\
\text { saltar, lançar e arremessar; } \\
\text { - Identificar a corrida, o } \\
\text { salto, o lançamento e o } \\
\text { arremesso como } \\
\text { construções culturais que } \\
\text { buscaram responder aos } \\
\text { desafios impostos pela } \\
\text { natureza, de modo a } \\
\text { compreender as formas } \\
\text { originais de tais } \\
\text { movimentos corporais; } \\
\text { - Vivenciar brincadeiras que } \\
\text { encenem os desafios } \\
\text { impostos ao homem pela } \\
\text { natureza na Pré-história. }\end{array}$ & 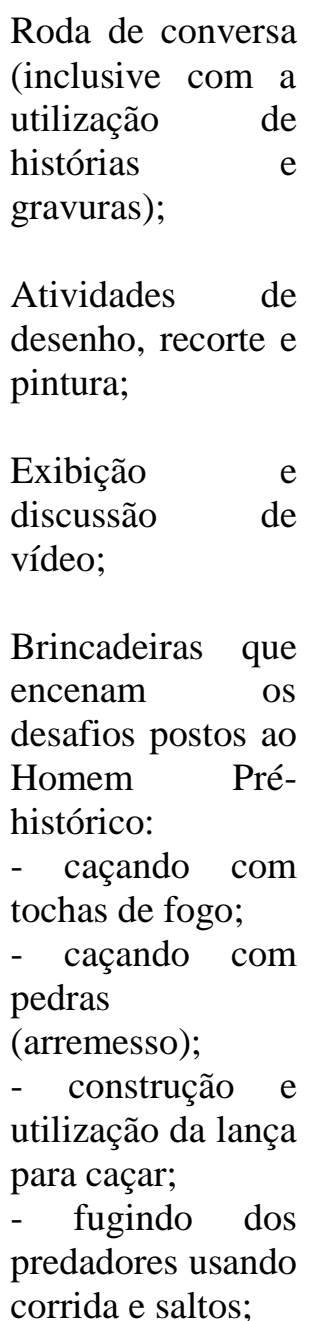 & $\begin{array}{l}\text { Livro que aborda a dimensão } \\
\text { histórica que reveste as } \\
\text { atividades corporais humanas } \\
\text { como correr, saltar, lançar e } \\
\text { arremessar (produção própria } \\
\text { do professor); } \\
\text { Folhas de papel, lápis de cor, } \\
\text { giz de cera. } \\
\text { Folhas de papel, pincel e tinta } \\
\text { guache. } \\
\text { Vídeo: } \\
\text { Discovery Channel } \\
\text { "Homem Pré-histórico: } \\
\text { vivendo entre as feras". } \\
\text { (Montagem produzida pelo } \\
\text { professor com recortes do } \\
\text { filme) } \\
\text { Cones (grandes e pequenos), } \\
\text { cordas, colchonetes, elástico, } \\
\text { bolas (esportivas), apito. }\end{array}$ \\
\hline
\end{tabular}

Quadro 3 - Síntese das atividades desenvolvidas na instrumentalização: unidade I Fonte: elaboração própria do autor 


\begin{tabular}{|c|c|c|c|}
\hline $\begin{array}{c}\text { Unidade } \\
\text { Didática II }\end{array}$ & Objetivos & Procedimentos & Recursos \\
\hline $\begin{array}{c}\text { Os } \\
\text { movimentos } \\
\text { básicos do } \\
\text { ser humano } \\
\text { nas } \\
\text { modalidades } \\
\text { do atletismo }\end{array}$ & $\begin{array}{l}\text { - Identificar diferentes } \\
\text { provas de atletismo que } \\
\text { envolvem o saltar, o } \\
\text { correr, o lançar e o } \\
\text { arremessar; } \\
\\
\text { - Compreender a corrida } \\
\text { com obstáculo, a corrida } \\
\text { sem obstáculo, o salto em } \\
\text { altura e o salto em } \\
\text { distância do atletismo } \\
\text { como expressões } \\
\text { contemporâneas dos } \\
\text { movimentos básicos do } \\
\text { homem; } \\
\\
\text { - Experimentar, de forma } \\
\text { não competitiva, diferentes } \\
\text { modos de correr, saltar, } \\
\text { lançar e arremessar; }\end{array}$ & 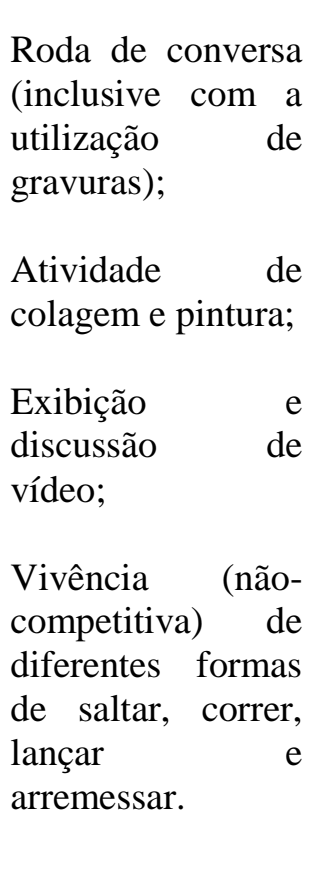 & $\begin{array}{l}\text { Cones (grandes e pequenos), } \\
\text { cordas, colchonetes, elástico, } \\
\text { bolas (esportivas), apito; } \\
\text { Vídeo (montagem elaborada } \\
\text { pelo professor, mostrando } \\
\text { diferentes formas saltar, } \\
\text { lançar e arremessar no } \\
\text { atletismo); } \\
\text { Folhas de papel, pincel, } \\
\text { barbante, palitos, lápis e lápis } \\
\text { de cor. }\end{array}$ \\
\hline
\end{tabular}

Quadro 4 - Síntese das atividades desenvolvidas na instrumentalização: unidade II Fonte: elaboração própria do autor

Embora não seja possível descrever detalhadamente os momentos de cada uma das aulas, algumas atividades merecem ser mencionadas, ainda que de forma sintética.

A primeira atividade para transmitir o conhecimento aos alunos foi iniciada com uma roda de conversa na qual buscamos situar como característica central da Pré-história a ausência da escrita, fator comumente utilizado como marco para periodização da evolução humana - em Pré-história e História. Mostrando fotos e gravuras aos alunos, destacamos que, naquela ocasião, os seres humanos, mesmo sem dominar a linguagem escrita, pintavam, nas paredes das cavernas, muitas ações relacionadas ao seu cotidiano. Ao questionar os alunos sobre o que significavam aqueles desenhos, demos início ao processo de apropriação do conhecimento sobre o modo de vida do homem pré-histórico.

Para relacionar as fotos e gravuras com as atividades desenvolvidas naquele contexto para manutenção da própria existência, contamos uma história que destacou, dentre outros, a forma de moradia, a produção de instrumentos e a caça como aspectos que marcavam a vida humana naquela época. Em linhas gerais, a história, produzida e contada aos alunos, buscou transmitir o entendimento de que as atividades corporais foram construídas historicamente como resposta aos desafios impostos pela natureza e pela relação com os outros homens.

Para contar a história aos alunos, foi utilizada uma espécie de livro produzido por educandos dos anos finais do ensino fundamental, sob minha orientação. Sua produção foi realizada da seguinte forma: após trabalharmos diferentes dimensões do conteúdo atletismo, eles foram desafiados a ilustrar, com desenhos, alguns recortes de texto fornecidos pelo professor, a fim de sintetizar o trabalho pedagógico desenvolvido. Com os alunos da educação infantil e do primeiro ano do ensino fundamental, mostramos algumas 
ilustrações desse livro e narramos uma história sobre a importância da corrida, do salto, do arremesso e do lançamento para a vida humana na Pré-história.

Buscamos destacar, inicialmente, que a postura bípede é resultado de um longo processo histórico e cultural: nem sempre o ser humano teve a postura que temos hoje, pois houve uma época em que as pessoas que habitavam nosso mundo utilizavam as mãos e os pés para se locomoverem, assumindo uma postura quadrúpede. Hoje, quando ainda somos crianças, as pessoas que convivem conosco nos ensinam, desde cedo, a caminhar, nos transmitindo a postura bípede.

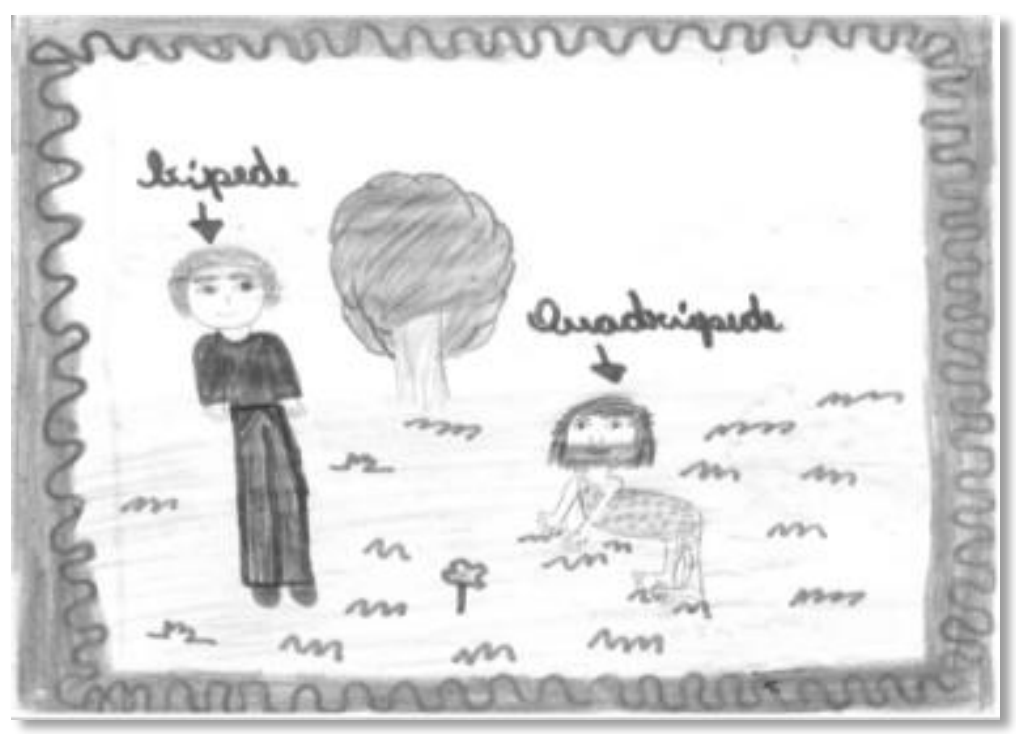

Figura 1 - Desenho sobre as posturas quadrúpede e bípede

Fonte: arquivo pessoal do autor

Em seguida, destacamos que essa transformação postural não ocorreu por acaso e sim como resposta aos desafios impostos pela natureza às pessoas que viviam naquela época: provavelmente, para retirar uma fruta da árvore, ele ficou de pé e descobriu uma nova postura corporal (FIGURA 2), que passou a ser ensinada a todas as pessoas que viviam na Pré-história. Hoje, todos incorporaram o ficar de pé ao seu comportamento (FIGURA 3). 


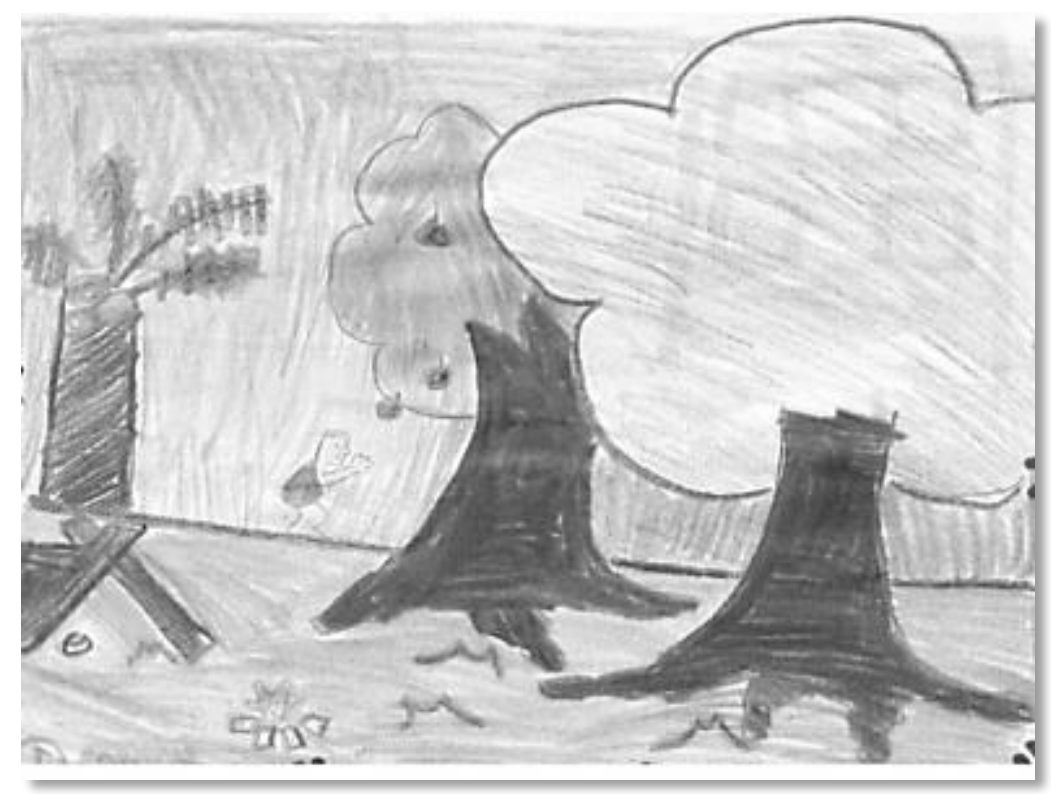

Figura 2 - Desenho sobre a descoberta do novo comportamento: ficar de pé Fonte: arquivo pessoal do autor

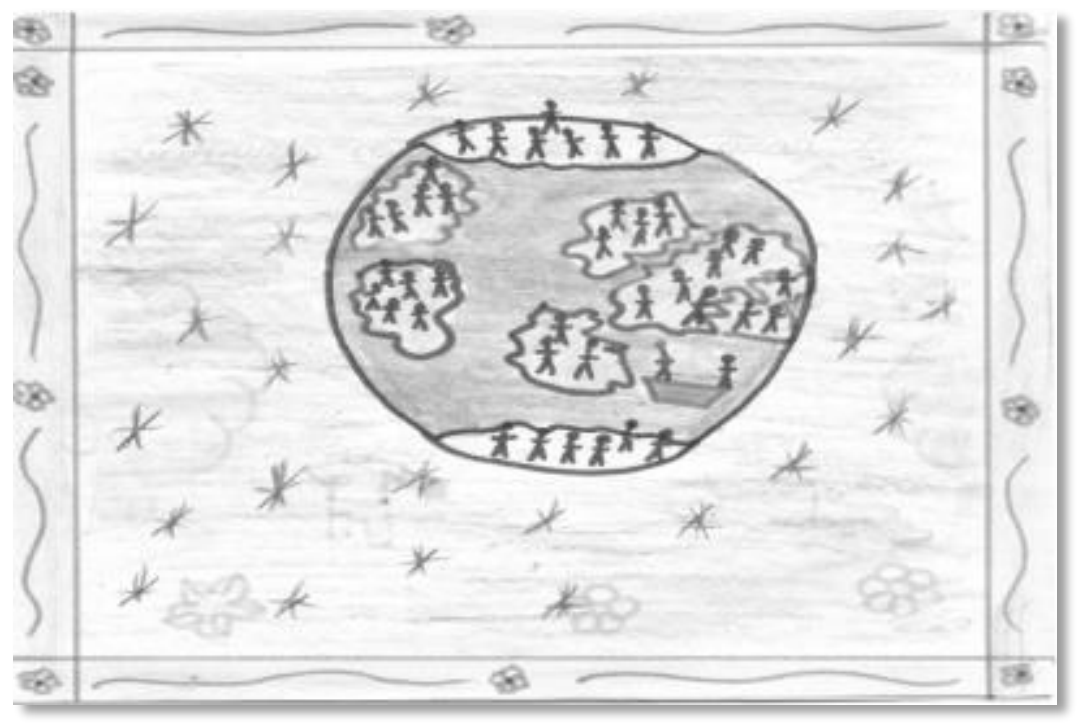

Figura 3 - Desenho sobre a socialização da postura humana bípede Fonte: arquivo pessoal do autor

Buscou-se explicitar aos alunos como era o modo de vida naquele contexto. Para tanto, além de abordar a questão da moradia, na relação com a proteção do frio e de predadores, destacamos que as condições de vida da época passaram a exigir a utilização de movimentos corporais como forma de manutenção da sua própria existência. Para tanto, destacamos, por exemplo, que a corrida e os saltos eram usados, dentre outras finalidades, para fugir dos animais (FIGURA 4). 


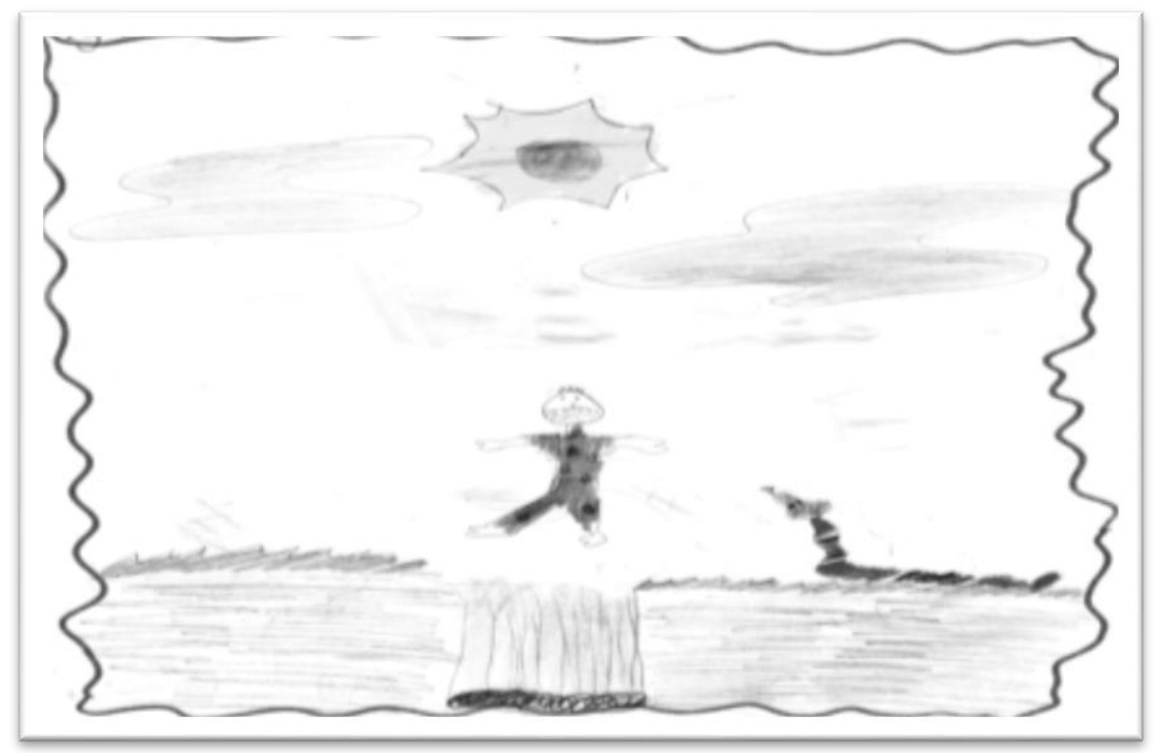

Figura 4 - Desenho sobre a utilização da corrida e do salto para fugir de predadores Fonte: arquivo pessoal do autor

Mostramos que a utilização das mãos também era importante, explicando que, provavelmente, para se proteger, alguém teve que arremessar uma pedra para afastar um predador e, assim, nesta atividade, descobriu que também poderia utilizar essa ação para caçar (Figura 5).

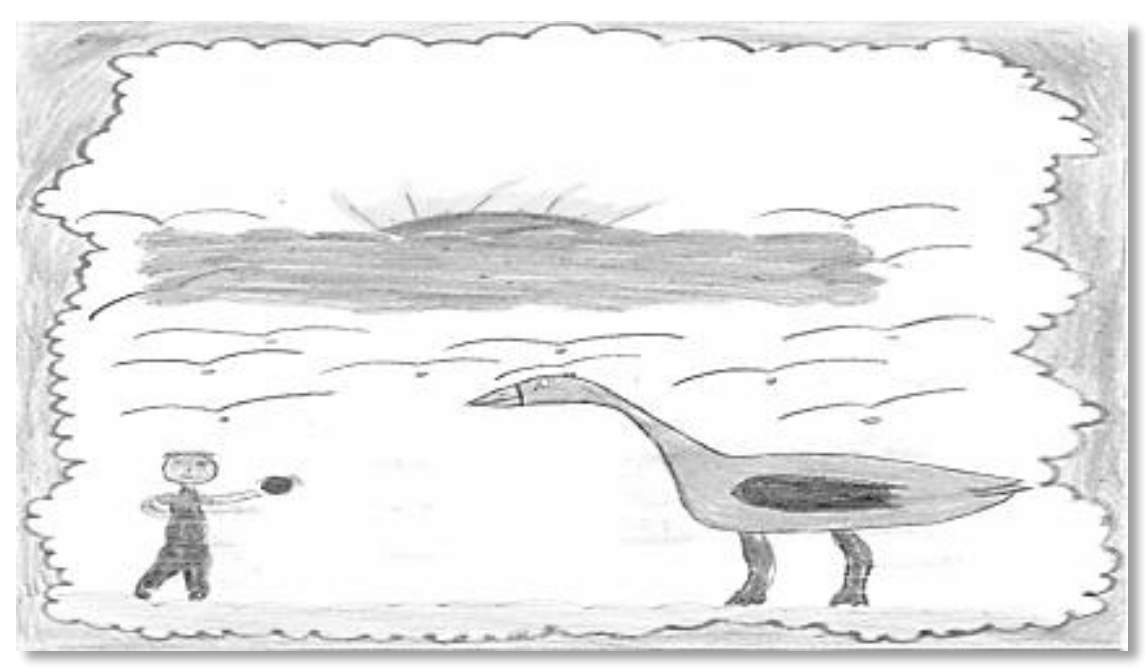

Figura 5 - Desenho sobre um arremesso de pedra para se proteger dos animais Fonte: arquivo pessoal do autor

Além disso, explicitamos aos alunos que, para caçar, as pessoas que viviam na Préhistória começaram a fabricar instrumentos, como pedras lascadas e lanças, que passaram a ser utilizadas em seu dia a dia (FIGURA 6). 


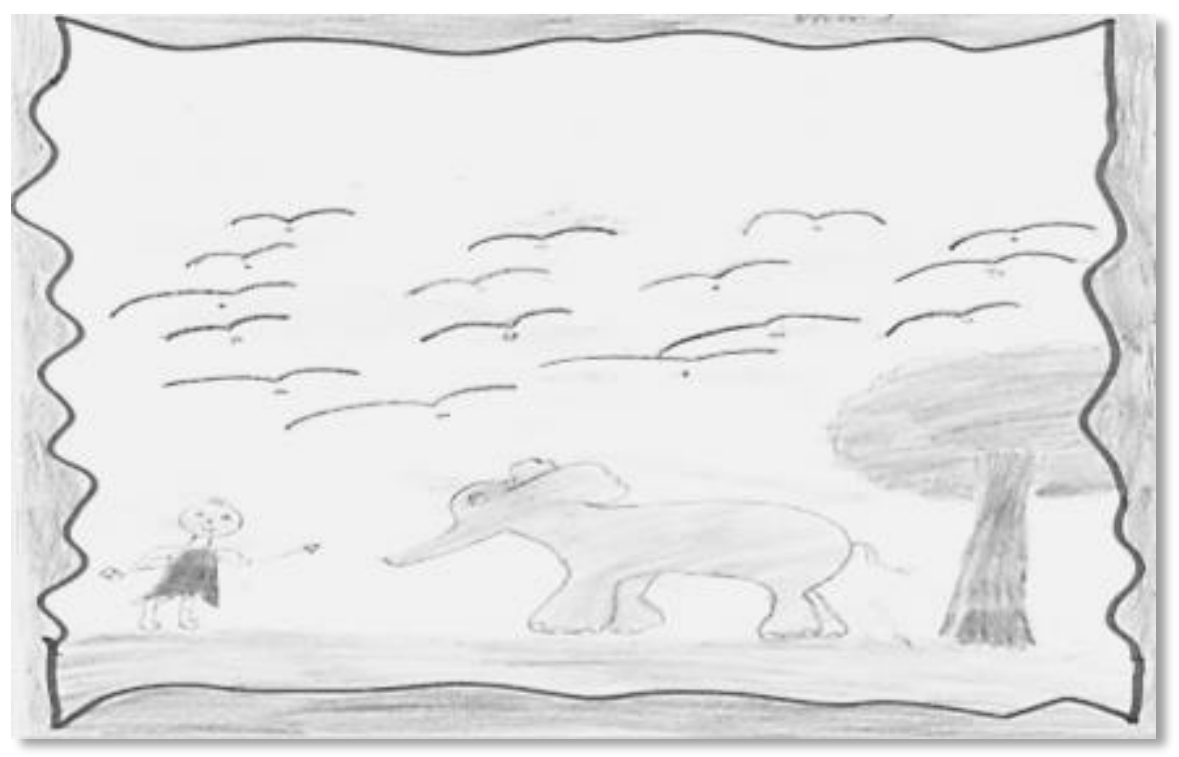

Figura 6 - Desenho de um lançamento durante a caça na Pré-história Fonte: arquivo pessoal do autor

Assim, discutindo essas e outras ilustrações, buscamos realizar uma primeira aproximação dos alunos ao conhecimento historicamente elaborado sobre o tema, enfatizando que, em virtude das condições de vida impostas pela natureza naquele contexto, os seres humanos utilizavam diferentes movimentos corporais como forma de manutenção da própria existência. Após discutir essa história com os alunos, passamos a um segundo momento: o de encenar, através de brincadeiras, a vida humana naquela época.

Para tanto, no início de cada aula, explicamos a dinâmica das atividades e seu objetivo, lançando questões voltadas à vida humana na Pré-história. Dentre as brincadeiras realizadas, encontra-se a que encenou a utilização da corrida, dos saltos e, também, dos rolamentos. Trata-se de uma atividade na qual os alunos deviam ultrapassar os obstáculos impostos pela natureza com o intuito de fugir dos "predadores", que, subitamente, surgiam na "floresta" após deixar sua toca, representada por um conjunto de colchões. Um dos alunos representava um "predador feroz" (leão) que deixava sua toca à procura de alimento. Nesse momento, "homens e mulheres das cavernas" deviam fugir do predador, atravessando variados obstáculos, como "rio com jacaré" e "cobras dormindo entre as árvores", os quais se encontravam dispostos na "floresta". Para estimular a solidariedade entre os alunos, os que eram pegos pelo "predador feroz" deveriam se fingir de feridos, se mantendo deitados, até que outro "hominídeo" o salvasse, lhe dando as mãos para ajudá-lo a levantar. Após discutir a encenação, os alunos foram capazes de afirmar que a corrida, os saltos e, também, o rolamento, eram importantes para os seres humanos da época se manterem vivos, pois serviam para fugir dos animais ferozes.

Outra atividade desenvolvida encenou os momentos em que os hominídeos saíam à caça. Espalhados na quadra, concebida como floresta, a maioria dos alunos assumia o papel de animais inofensivos que serviam de alimento para o "homem das cavernas". Este corria segurando uma bola, apresentada como uma pedra lascada. Com capacidade de ferir os animais, essa bola, concebida como pedra, deveria ser arremessada quando a distância o permitisse acertar o alvo em movimento. Aos alunos que representavam os animais inofensivos, cabia fugir, para que não fossem atingidos pelas "pedras". Quando atingidos, tinham que se deitar, fingindo-se de ferido, aguardando até o momento em que um colega os ajudasse a levantar, para retornar à fuga. Ao final da atividade, uma conversa com os 
alunos buscou evidenciar como as atividades corporais de arremesso e corrida eram importantes para satisfazer a necessidade de se alimentar.

Nessa mesma linha, de simulação de caça na Pré-história, outras atividades foram realizadas. Diferente da anterior, essas brincadeiras encenavam as ações voltadas à conquista do alimento por meio do trabalho coletivo na Pré-história ${ }^{7}$. Em uma delas, alguns alunos representavam os "batedores" que, utilizando suas "tochas" (pequenos cones), deveriam assustar os "animais" (outros alunos), a fim de levá-los diretamente ao outro grupo de "caçadores" que se mantinha a espreita. Ao final, explicamos aos alunos a importância desse tipo de atividade - coletiva - para o desenvolvimento de uma forma mais elaborada de comunicação entre os homens.

Além das brincadeiras que buscavam encenar a vida humana na Pré-história, tivemos a oportunidade de discutir com os alunos a importância da produção de instrumentos, sobretudo para o aprimoramento da caça e, consequentemente, para o desenvolvimento humano. Construímos, coletivamente, pequenas lanças de papel com pontas arredondadas para serem levadas para casa. Além disso, os alunos puderam vivenciar o lançamento utilizando uma espécie de lança com ponta de papel produzida pelo próprio professor. Nesse caso, o objetivo não era lançar mais longe que o companheiro e, sim, acertar os "animais pré-históricos" que serviriam de alimento.

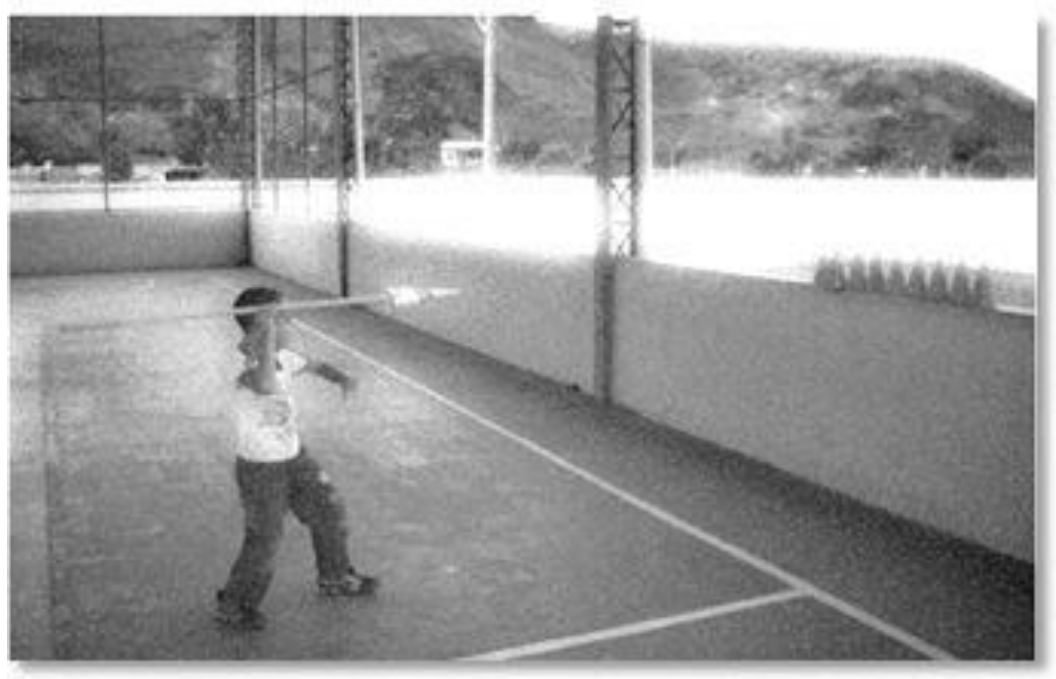

Figura 7 - Fotografia da atividade de encenação "caçando com lança" Fonte: arquivo pessoal do autor ${ }^{8}$

Além dos lançamentos, também possibilitamos aos alunos vivenciar diferentes formas de saltar: primeiro, contextualizamos a vivência do salto em altura e em distância, encenando, individualmente, o "saltar a cobra entre as árvores" e o "saltar o rio com jacarés", respectivamente. Depois, mostramos uma montagem com vídeos contemporâneos de modalidades do atletismo e discutimos porque não precisamos competir para vivenciar as atividades corporais que, hoje, estão presentes no atletismo. Os alunos puderam se aproximar do entendimento de que o surgimento do atletismo imprimiu novas configurações aos saltos, corridas, arremessos e lançamentos, tais como o estabelecimento de regras (normatização), da competição e da preocupação com o aprimoramento técnico, para alcançar maior rendimento ${ }^{9}$.

Ao discutir o desenvolvimento técnico do salto em distância a partir de gravuras e vídeos, os alunos do primeiro ano do ensino fundamental foram desafiados a experimentar 
os saltos com estilos tesoura e rolo ventral, ao invés de só saltar "livremente", como faziam quando estavam matriculados na educação infantil. Não se trata, nesse caso, de negar a liberdade de movimento da criança, mas, sim, de ampliar as possibilidades de acesso ao conhecimento produzido historicamente.

A última atividade desenvolvida no processo de transmissão do conhecimento aos alunos foi a visualização e discussão de um vídeo cuja montagem desenvolvida pelo professor foi realizada a partir de diferentes cenas do documentário "Homem Pré-histórico: vivendo entre as feras" ${ }^{\text {10 }}$. Ao assisti-lo, os alunos comentavam as cenas demonstrando reconhecimento da relação entre as encenações desenvolvidas durante o processo pedagógico e as atividades do homem pré-histórico, abordadas no vídeo. Após discutir o documentário, os alunos foram desafiados a desenhar algum trecho que lhes chamou a atenção para, posteriormente, apresentá-lo aos colegas. A título de exemplo, podemos destacar o trabalho produzido pelo aluno que buscou representar a cena na qual os homens pré-históricos caçavam coletivamente, com tochas, criando uma emboscada que forçava os animais a se jogarem do penhasco (FIGURA 8).

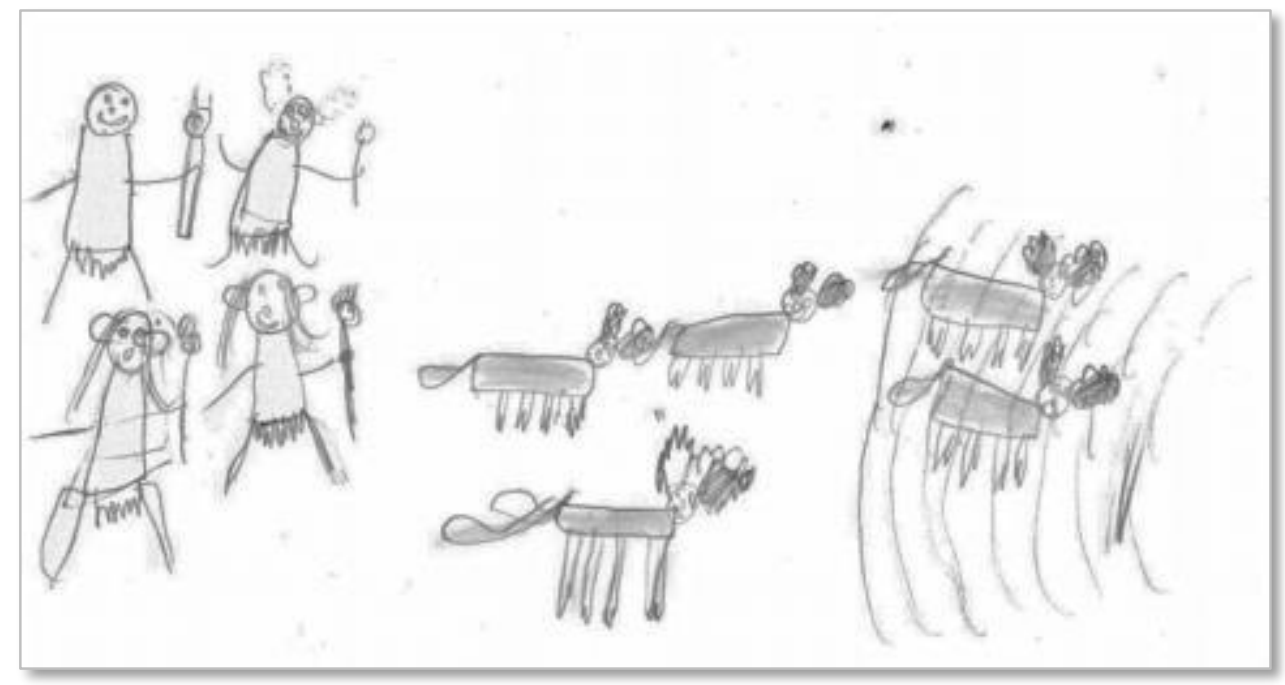

Figura 8 - Desenho sobre a ação coletiva do Homem pré-histórico durante a caça Fonte: arquivo pessoal do autor

Vale destacar que embora algumas atividades descritas anteriormente tenham utilizado brincadeiras para facilitar a apropriação do conteúdo, o processo pedagógico não foi direcionado pelas "atividades prazerosas" para as crianças, muito menos foi orientado pelo espontaneísmo. Até as aulas realizadas com brincadeiras continham sempre um momento de exposição do professor, no qual eram abordados os aspectos fundamentais do conteúdo, a explicação das brincadeiras a serem realizadas, assim como uma discussão para que os alunos compreendessem a relação entre a atividade realizada e os objetivos traçados. O que quero enfatizar com esse destaque é o fato de que discordo completamente de um entendimento muito comum nos dias de hoje, qual seja, o de que devemos trabalhar na educação infantil apenas com atividades espontâneas, que tragam prazer ou que sejam do interesse das crianças.

Conforme ressalta Arce (2010) a educação infantil não é o lugar do espontâneo, das brincadeiras prazerosas ou das atividades orientadas pelos desejos e interesses das crianças, mas, sim, parte de uma instituição que deve manter o ato de ensinar como eixo nuclear do trabalho pedagógico. Conforme explica a autora, a defesa do ensino na educação infantil 
não ausenta, da escola, elementos como o prazer, o carinho e o afeto. Eles convivem lado a lado com a transmissão do conhecimento científico, tal como buscamos evidenciar com a descrição das atividades desenvolvidas na instrumentalização. Porém, o ato de homogeneização do trabalho pedagógico exige processos que nem sempre são prazerosos, como os de controle do corpo, por exemplo. Assim explica a autora:

\begin{abstract}
Os alunos apresentam características individuais que trazem a heterogeneidade, porém, o professor fará com que todos se apropriem dos conhecimentos que quer transmitir, aí reside o ato de homogeneização ao qual o trabalho educativo deve estar atento. Para isso existirá sim um processo de controle do corpo, ou um processo de disciplina, demandado pelo próprio trabalho intelectual que exige: atenção, concentração, silêncio, capacidade de ficar sentado. Não queremos afirmar que a criança não poderá correr, pular, rolar, uma vez que essas atividades, assim como o brincar, são fundamentais, todavia, a atividade intelectual exigirá dela o controle progressivo de seus movimentos. E isso também terá que ser produzido pelo professor de forma intencional em seus alunos (ARCE, 2010, p.33).
\end{abstract}

\title{
Catarse
}

Saviani (2006) situa a catarse como o quarto passo do método dialético de transmissão do conhecimento escolar e o define como momento de expressão elaborada da nova forma de entendimento da prática social a que se ascendeu. "Trata-se da efetiva incorporação dos instrumentos culturais, transformados agora em elementos ativos de transformação social" (SAVIANI, 2006, p. 72). Pode-se dizer que a catarse é a demonstração teórica do ponto de chegada, do nível superior atingido pelos alunos (GASPARIN, 2005).

Neste momento, os alunos manifestaram uma nova compreensão sobre a importância dos movimentos corporais na Pré-história. Se, anteriormente, não identificavam as formas originais dos saltos, corridas, lançamentos e arremessos, ao final do processo, eles aprimoraram sua compreensão, uma vez que identificaram a utilização dessas atividades corporais pelo homem pré-histórico como forma de garantir sua própria vida, seja para caçar, seja para se proteger dos predadores em um contexto histórico no qual o homem caçava, coletava alimentos e ocupava cavernas para se proteger do frio, da chuva ou de predadores.

Indo mais além, os alunos do primeiro ano do ensino fundamental ainda puderam aprimorar o conhecimento sobre as atuais modalidades de atletismo, compreendendo que diferente do correr, saltar, lançar e arremessar do homem pré-histórico, as provas de atletismo imprimiram novos significados a essas atividades corporais. Os alunos puderam destacar a definição de regras e da competição como elementos norteadores do atletismo que o diferencia das formas originais dos movimentos corporais estudados. Além disso, conheceram dois estilos do salto em altura: tesoura e rolo ventral. Identificaram modalidades, como corrida com/sem obstáculo, salto em altura, salto em distância, lançamento de dardo e arremesso de peso. Compreenderam, ainda, que é possível vivenciálas sem a necessidade de competir com os colegas.

A expressão prática da síntese envolveu discussão direcionada a partir de imagens e fotos dos próprios alunos realizando as atividades. A produção de desenhos foi outra atividade realizada (FIGURA 9). 


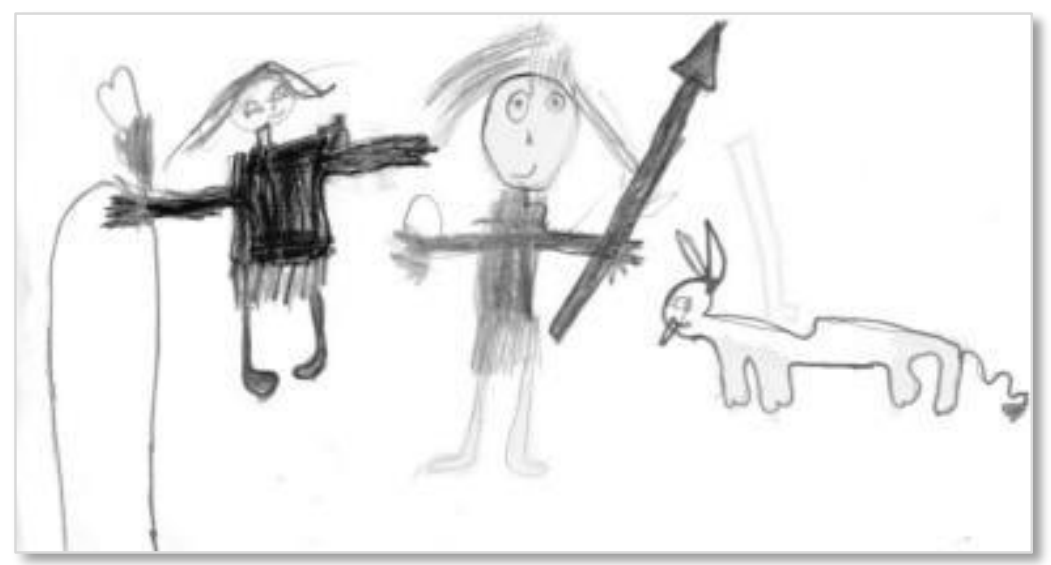

Figura 9 - Desenho sobre homem (e mulher) na Pré-história caçando com lança, tocha e pedra Fonte: arquivo pessoal do autor

Ao final do processo, produzimos um mural para exposição das atividades desenvolvidas. Nele, constavam fotos das atividades realizadas, desenhos produzidos e alguns materiais utilizados nas aulas, como a "lança", por exemplo. Assim, os alunos da educação infantil ao primeiro ano do ensino fundamental puderam conversar com seus pais sobre o que aprenderam nas aulas de Educação Física, uma vez que o mural foi exposto na "Feira Cultural", evento realizado anualmente na escola.

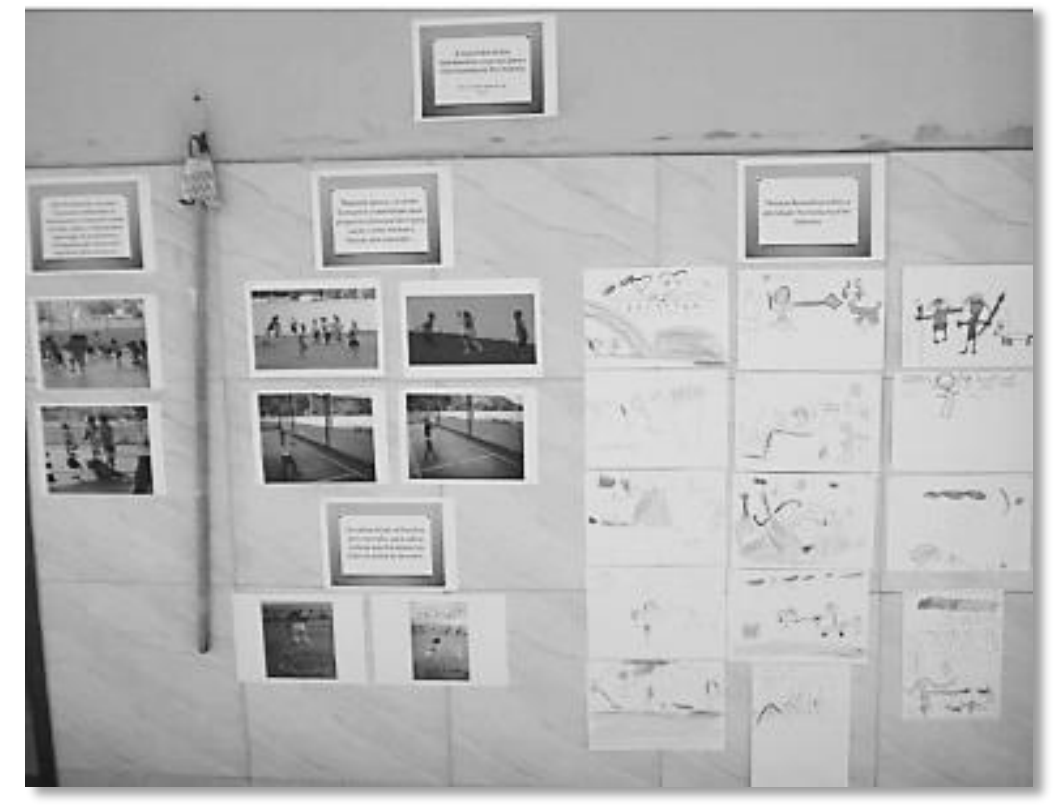

Figura 10 - Fotografia do mural exposto na Feira Cultural da escola Fonte: arquivo pessoal do autor

\section{Prática social final do conteúdo}

A prática social final é a nova maneira de compreender a realidade e de posicionarse nela: é a manifestação da nova postura prática, da nova atitude, da nova visão do conteúdo no cotidiano, a se manifestar no retorno à prática social (GASPARIN, 2005). A 
realização dessa fase com os alunos, segundo Gasparin (2005), pode envolver, basicamente, a manifestação da nova atitude prática e a proposta de ação para expressar essa nova atitude.

Partindo desse entendimento, buscou-se firmar com os alunos novas intenções e predisposições para colocar em prática o conhecimento apropriado. Aprender mais sobre o atletismo, incorporar o repertório de movimentos vivenciados à sua prática social e socializar o conhecimento adquirido foram algumas das propostas adotadas. A respeito das propostas de ação, sugerimos: assistir as provas de atletismo nas olímpiadas para identificar quais modalidades não foram estudadas durante o ano; vivenciar, em sua própria comunidade, brincadeiras que utilizam saltos, arremessos, lançamentos e corridas; conversar com os pais, familiares e amigos a respeito das atividades produzidas durante a unidade didática, a fim de expor o que aprenderam.

\begin{tabular}{|c|c|}
\hline \multicolumn{2}{|c|}{ Intenções e propostas de ação } \\
\hline $\begin{array}{c}\text { Manifestação da nova atitude prática } \\
\text { (intenções) }\end{array}$ & $\begin{array}{c}\text { Proposta de ação da nova postura prática } \\
\text { (compromissos) }\end{array}$ \\
\hline 1- Aprender mais sobre o atletismo & $\begin{array}{c}\text { 1- Assistir as provas de atletismo nas } \\
\text { olímpiadas para identificar quais modalidades } \\
\text { não foram estudadas durante o ano; }\end{array}$ \\
\hline $\begin{array}{c}\text { 2- Incorporar o repertório de } \\
\text { movimentos vivenciados à sua prática } \\
\text { social }\end{array}$ & $\begin{array}{c}\text { 2- Vivenciar, em sua própria comunidade, } \\
\text { brincadeiras que utilizam saltos, arremessos, } \\
\text { lançamentos e corridas; }\end{array}$ \\
\hline $\begin{array}{c}\text { 3- Socializar o conhecimento } \\
\text { adquirido }\end{array}$ & $\begin{array}{c}\text { 3- Conversar com os pais, familiares e amigos } \\
\text { a respeito das atividades produzidas durante a } \\
\text { unidade didática, a fim de expor o que } \\
\text { aprenderam; }\end{array}$ \\
\hline
\end{tabular}

Quadro 5: Manifestação da nova atitude prática e propostas de ação dos alunos Fonte: elaboração própria do autor

\section{Considerações finais}

A dificuldade dos professores na elaboração de planejamentos fundamentados na pedagogia histórico-crítica, já indicada por Gasparin (2005) e Marsiglia (2011), nos instigou a produzir este texto sobre a prática pedagógica na Educação Física. Trata-se, apenas, de uma possibilidade que não esgota as inúmeras formas de trabalho pedagógico com o conteúdo e método em questão.

As reflexões apresentadas nos permitem afirmar que a pedagogia histórico-crítica é uma alternativa viável para o trabalho educativo na Educação Física com crianças de 3 a 7 anos. A ênfase na transmissão do conhecimento sistematizado não significou ausência de prazer, uma vez que os alunos, em diversas ocasiões, se apresentaram bastante motivados e demonstraram estar se divertindo com certas atividades, sobretudo com as encenações. Ao final do processo, os alunos não só avançaram em sua compreensão sobre o tema trabalhado como também ampliaram seu repertório cultural de movimento.

Se levarmos em consideração o conhecimento com o qual os alunos chegaram à escola, pode-se afirmar que o repertório cultural adquirido abriu novas possibilidades para o trabalho educativo a ser realizado posteriormente, ao mesmo tempo em que possibilitou o desenvolvimento de novas capacidades nos alunos. Acreditamos que um trabalho sequencial, organizado e dirigido com base na pedagogia histórico-crítica desde a educação 
infantil pode significar aos alunos um importante passo no processo de apropriação dos conhecimentos historicamente produzidos pela humanidade, inclusive na Educação Física.

\section{Referências}

ARCE, A. O Referencial Curricular Nacional para a Educação Infantil e o espontaneísmo: (re)colocando o ensino como eixo norteador do trabalho pedagógico com crianças de 4 a 6 anos. In: ARCE, A; MARTINS, L. M. (org.). Quem tem medo de ensinar na Educação Infantil? Em defesa do ato de ensinar. 2.ed. Campinas: Alínea, 2010.

ARCE, A. Pedagogia da infância ou Fetichismo da infância?. In: DUARTE, N. (Org.). Crítica ao fetichismo da individualidade. Campinas: Autores Associados, 2004.

ARCE, A; MARTINS, L. M (org.). Quem tem medo de ensinar na educação infantil? Em defesa do ato de ensinar. 2. Ed. São Paulo: Editora Alínea, 2010.

ARCE, A; SILVA, D. A. M; VAROTTO, M. Ensinando ciências na educação infantil. Campinas: Editora Alínea, 2011.

COLETIVO DE AUTORES. Metodologia do ensino de educação física. São Paulo: Cortez, 1992.

DUARTE, N. A individualidade para-si: contribuição a uma teoria histórico-social da formação do indivíduo. 2.ed. Campinas: Autores Associados, 1999.

DUARTE, N. Sociedade do conhecimento ou sociedade das ilusões? Quatro ensaios crítico-dialéticos em filosofia da educação. Campinas: Autores Associados, 2003.

DUARTE, N. Vigotski e o "aprender a prender": crítica às apropriações neoliberais $e$ pós-modernas da teoria vigotskiana. 4. Ed. Campinas: Autores Associados, 2006.

DUARTE, N; EIDT, N. Contribuições da teoria da atividade para o debate sobre a natureza da atividade de ensino escolar. Psicologia da Educação, v. 24, p. 51-72, 2007.

ENGELS, F. Sobre o papel do trabalho na transformação do macaco em homem. In: ANTUNES, R (Org.). A dialética do trabalho: escritos de Marx e Engels. São Paulo: Expressão popular, 2004.

GASPARIN, J. L. Uma didática para a pedagogia histórico-crítica. 3. Ed. Campinas: Autores Associados, 2005.

HOMEM PRÉ-HISTÓRICO: VIVENDO ENTRE AS FERAS. Direção: Pierre de Lespiniois. EUA: Discovery Channel, 2002.

LEONTIEV, A. N. Desenvolvimento do psiquismo. Lisboa: Livros Horizonte, 1978.

LEONTIEV, A. N. Uma contribuição à teoria do desenvolvimento da psique infantil. In: VIGOTSKI, L. S; LURIA, A. R; LEONTIEV, A. N. Linguagem, desenvolvimento e aprendizagem. 12. Ed. São Paulo: Ícone, 2012. 
MARSIGLIA, A. C. G. A prática pedagógica histórico-crítica na educação infantil e no ensino fundamental. Campinas: Autores Associados, 2011.

MARTINS, L. M. O desenvolvimento do psiquismo e a educação escolar: contribuições à luz da psicologia histórico-cultural e da pedagogia histórico-crítica. Tese (Livre Docência em Psicologia da Educação). Universidade Estadual Paulista, Bauru, 2011.

MARTINS, L. M. Pedagogia histórico-crítica e psicologia histórico-cultural. IN: MARSIGLIA, A. C. G (org). Pedagogia histórico-crítica: 30 anos. Campinas: Autores associados, 2011.

MARX, K. Processo de trabalho e processo de valorização. In: ANTUNES, R. (org.). A dialética do trabalho: escritos de Marx e Engels. São Paulo: Expressão popular, 2004.

PASQUALINI, J. C. A educação escolar da criança pequena na perspectiva históricocultural e histórico-crítica. IN: MARSIGLIA, A. C. G (org). Pedagogia histórico-crítica: 30 anos. Campinas: Autores associados, 2011.

PASQUALINI, J. C. O papel do professor e do ensino na educação infantil: a perspectiva de Vigotski, Leontiev e Elkonin. In: DUARTE, N; MARTINS, L. M (orgs.). Formação de professores: limites contemporâneos e alternativas necessárias. São Paulo: Cultura Acadêmica, 2010.

ROSSLER, J. H. Sedução e alienação no discurso construtivista. Campinas: Autores Associados, 2006.

SAVIANI, D. Escola e Democracia. 38. Ed. Campinas: Autores Associados, 2006.

SAVIANI, D. Pedagogia histórico-crítica: primeiras aproximações. 9. Ed. Campinas: Autores Associados, 2005.

SAVIANI, D. Trabalho e Educação: fundamentos ontológicos e históricos. In: Revista Brasileira de Educação, v.12, n.34, p. 152-165, 2007.

VYGOTSKI, L. S. Obras escogidas. Tomo III. Madri: Visor, 1995.

NOTAS:

${ }^{1} \mathrm{O}$ autor é doutorando em Educação pela Universidade Federal de Juiz de Fora (UFJF) e professor de educação física da rede pública municipal de ensino de Juiz de Fora/MG. E-mail: leodocena@ yahoo.com.br

${ }^{2}$ Para compreender a relação entre a Psicologia histórico-cultural e a Pedagogia histórico-crítica, pode-se recorrer à Martins (2011).

3 Atividade dominante ou principal, segundo Leontiev (1978; 2012), é aquela cujo desenvolvimento condiciona as principais mudanças nos processos psíquicos da criança e as particularidades psicológicas da sua personalidade num dado estágio de desenvolvimento. Comporta três características: 1) é aquela sob a forma da qual aparecem e no interior da qual se diferenciam tipos novos de aprendizagem; 2) é aquela na qual se formam ou se organizam seus processos psíquicos particulares; 3) é aquela de que dependem as mudanças psicológicas fundamentais da personalidade da criança numa dada etapa de seu desenvolvimento (LEONTIEV, 1978).

${ }^{4}$ Segundo o Coletivo de Autores (1992), o paradigma da aptidão física é uma perspectiva de educação física que tem como objeto de estudo o desenvolvimento da aptidão física do homem. Tal perspectiva tem 
contribuído historicamente para a defesa dos interesses do bloco no poder, na medida em que "Apóia-se nos fundamentos sociológicos, filosóficos, antropológicos, psicológicos e, enfaticamente, nos biológicos para educar o homem forte, ágil, apto, empreendedor, que disputa uma situação privilegiada na sociedade competitiva de livre concorrência: a capitalista. Procura, através da educação, adaptar o homem à sociedade, alienando-o de sua condição de sujeito histórico, capaz de interferir na transformação da mesma. Recorre à filosofia liberal para a formação do caráter do indivíduo, valorizando a obediência, o respeito às normas e à hierarquia. Apóia-se na pedagogia tradicional influenciada pela tendência biologicista para adestrá-lo" (COLETIVO DE AUTORES, 1992, p.36).

${ }^{5}$ Uma análise detalhada do processo de produção e reprodução da cultura pode ser obtida em Duarte (2003) e Duarte (2006).

${ }^{6}$ Por uma opção didática, optamos por apresentar a experiência descrevendo as atividades desenvolvidas nos diferentes momentos do processo de transmissão do conhecimento que constitui a pedagogia histórico-crítica. Contudo, é importante ressaltar que, no desenvolvimento do trabalho educativo, os cinco momentos não são tomados de forma rígida, ou seja, leva-se em consideração a necessária articulação e interdependência entre identificação da prática social, problematização, instrumentalização, catarse e retorno à prática social, o que nos permite tomá-los como etapas que não se dão em pontos únicos e exclusivos no processo, tal como alerta Marsiglia (2011, p.74): "Na verdade, todos os momentos são imbricados e acontecem ao mesmo tempo, sendo separados apenas para fins didáticos. Existe um processo, um encaminhamento que segue determinadas diretrizes, mas não há um distanciamento entre um momento e outro, exceto por razões de exposição".

${ }^{7}$ Sobre o conceito de ações, consultar Leontiev (1978).

8 Fotografia produzida pelo autor. Os responsáveis do aluno fotografado autorizaram, por escrito, a divulgação da fotografia no presente artigo.

${ }^{9}$ Essa discussão foi realizada com os alunos do primeiro ano do ensino fundamental.

10 As atividades referentes ao documentário em questão foram desenvolvidas apenas com os alunos do primeiro ano do ensino fundamental. 